\title{
Damage to residual trees following commercial thinning by harvester and forwarder in a Pinus taeda stand in Southern Brazil
}

\author{
Danos às árvores remanescentes de um desbaste por harvester \\ e forwarder em um povoamento de Pinus taeda no sul do Brasil
}

\author{
Eduardo Silva Lopes ${ }^{1}$, Felipe Martins Oliveira ${ }^{2}$ e Andre Droog ${ }^{3}$
}

\begin{abstract}
Resumo
Objetivou-se neste trabalho avaliar os danos causados às árvores remanescentes de um povoamento florestal submetido ao desbaste pelo harvester e pelo forwarder com rodados de pneus. O estudo foi realizado em uma empresa localizada no Estado do Paraná, região Sul do Brasil, em povoamentos de Pinus taeda L. com idade de 12 anos submetido ao primeiro desbaste, nas declividades do terreno de 0 a $10^{\circ}$ e 10 a $20^{\circ}$. Foram avaliados os danos causados nas árvores pelos harvester e forwarder, por meio da intensidade, localização e dimensões. Os danos foram comparados pelo teste t ao nível de $5 \%$ de probabilidade, enquanto os dados das dimensões dos danos foram analisados por meio dos valores mínimos, médios e máximos. Os resultados mostraram um elevado percentual de danos nas árvores após a execução da colheita de madeira, com $36,1 \%$ e $29,1 \%$ nas declividades de 0 a $10^{\circ}$ e 10 a $20^{\circ}$, respectivamente, porém sem apresentar diferença estatística. Os maiores danos foram no tronco das árvores com $11,6 \%$, nas faces voltadas para a estrada e povoamento e com área média abaixo de $100 \mathrm{~cm}^{2}$, sendo tais resultados explicados pela movimentação da grua do harvester no corte das árvores selecionadas para desbaste seletivo. $O$ harvester de pneus causou elevados danos nas árvores do povoamento, não sendo recomendado este modelo de máquina na execução do primeiro desbaste em florestas plantadas.
\end{abstract}

Palavras-chave: Desbaste mecanizado, colheita de madeira, qualidade.

\begin{abstract}
This study assessed the damage to residual trees in forest stands thinned by both a wheeled harvester and a forwarder. Data collection took place at a company located in the State of Paraná, in Southern Brazil; in 12-year-old Pinus taeda stands conducted to their first thinning; and in terrains from 0 to $10^{\circ}$ and 10 to $20^{\circ}$ slope classes. Damage to residual trees was assessed by intensity, location, and wound area. Damage was compared by the t-test at a $5 \%$ probability level, while wound area was analyzed by minimum, mean and maximum values. Results showed high total damage percentages after the harvesting, with $36.1 \%$ and $29.1 \%$ in the 0 to $10^{\circ}$ and 10 to $20^{\circ}$ slopes, respectively, but without statistical difference. Most of the damage was caused by the movement of the harvester boom while cutting trees during the selective thinning process. Moreover, most of the damage appeared on the trunks of $11.6 \%$ residual trees, on the sides facing the road and the stand, with an mean wound area under $100 \mathrm{~cm}^{2}$. The wheeled harvester is not recommended for the first thinning in planted forests, because of the high damage to residual trees.
\end{abstract}

Keywords: Mechanized thinning, timber harvesting, wood quality.

\section{INTRODUCTION}

In Brazil, planted forests cover nearly 7.8 million hectares of the country's land surface; an increase of $0.8 \%$ over 2014 , of which $72.2 \%$ are Eucalyptus species and $20.2 \%$ are Pinus species. The wood from both species is destined for producing pulp and paper, wood paneling, lamination, sawing, plywood, charcoal-based steel, energy, etc. (IBÁ, 2016).

In order to obtain a high profitability in the wood production destined for sawing or lamination, forest stands need to be managed by thinning, which consists of removing a percentage of trees to provide better conditions for the residual trees to increase in volume and diameter. One of the thin-

\footnotetext{
${ }^{1}$ Associate Professor at Forestry Departament. UNICENTRO - Universidade Estadual do Centro-Oeste. PR 153 , KM 7 Postal Code: 21 - 84500000 - Irati, PR, Brasil. E-mail: eslopes@irati.unicentro.br.

2PhD Student. UNICENTRO - Universidade Estadual do Centro-Oeste. PR 153, KM 7 - Postal Code: 21 - 84500000 - Irati, PR, Brasil. E-mail: eng.oliveirafm@gmail.com.

${ }^{3}$ Forestry Student. UNICENTRO - Universidade Estadual do Centro-Oeste. PR 153, KM 7 - Postal Code: 21 - 84500000 Irati, PR, Brasil. E-mail: andredroog@gmail.com
}

Sci. For., Piracicaba, v. 46, n. 118, p. 167-175, jun. 2018 DOI: dx.doi.org/10.18671/scifor.v46n118.03 
ning aims is the reduction of the competition among trees, providing more resources to residual trees and giving them the space required to attain a higher growth rate (MULLER; ANGELI, 2006; SCHNEIDER; SCHNEIDER, 2008; OLIVEIRA et al., 2009).

Thinning is classified as systematic when all the trees in a given a row are removed at pre-established intervals, and as selective when trees are previously selected according to some characteristic, usually the dominated or defective ones, which are eliminated (MULLER; ANGELI, 2006).

Both systematic and selective thinning can be done by manual, semi-mechanized, or mechanized methods. In the thinning process, timber harvesting is mainly carried out by the cut-to-length (CTL) system due to the constant search for increased productivity and cost reduction.

According to Harstela (1999), the use of the CTL system in thinning provides the conditions to apply a strategy aimed at increasing the value of the wood produced, while Han \& Kellog (2000) affirmed that producing logs directly at the cutting site with the CTL system facilitates wood extraction and decreases stand damage.

However, a problem faced by the companies using mechanized thinning is the difficulty of machine mobility inside the forest stand due to limited space, resulting in low productivity and high operating costs (SPINELLI, NATI, 2009; BELBO, 2008; PETTY; KÄRHÄ, 2008; LOPES et al., 2016). In addition, there are other negative impacts such as loss of productive area, greater soil compaction, and damage to residual trees, with more significant difficulties in the higher slopes of the terrain (MALINOVSKI et al., 2006; RUMMER, 2002; VASILIAUSKAS, 2001).

Some studies show that the damage to trees in forest stands varies from 1 to $17 \%$, and can reach up to $45 \%$ in the first thinning; while up to $6 \%$ damage is acceptable (FRÖDING, 1992; LINEROS et al., 2003; McNEEL; BALAARD, 1992; MALINOVSKI et al., 1999; VIDRINE et al., 1999). Damaged trees with bark removed react by forming dry areas around the wound to prevent sap transportation, and suffer of an increased risk of infection by pathogens. Depending on the damage type, the tree may experience decreased growth and volume that can reach up to 20\% (WÄSTERLUND, 1992), depending on the wound size and its severity. These issues can cause technological problems that result in significant economic losses (LINEROS et al., 2003).

Therefore, studies that show damage, magnitude and location in different working conditions, as well as the wood harvesting machine responsible for damaging the trees, can help operation planning and contribute to the better use of resources and the sustainability of forest production.

Thus, the objective of this study was to assess damage to residual trees caused by both a wheeled harvest and a forwarder in a stand of Pinus taeda L. submitted to the first thinning.

\section{MATERIAL AND METHODS}

The study was carried out in a forest company located in the State of Paraná in Southern Brazil, at the geographic coordinates of $25^{\circ} 53$ ' 55,8 "S and $51^{\circ} 37^{\prime} 17,18^{\prime \prime} \mathrm{W}$ (Figure 1).

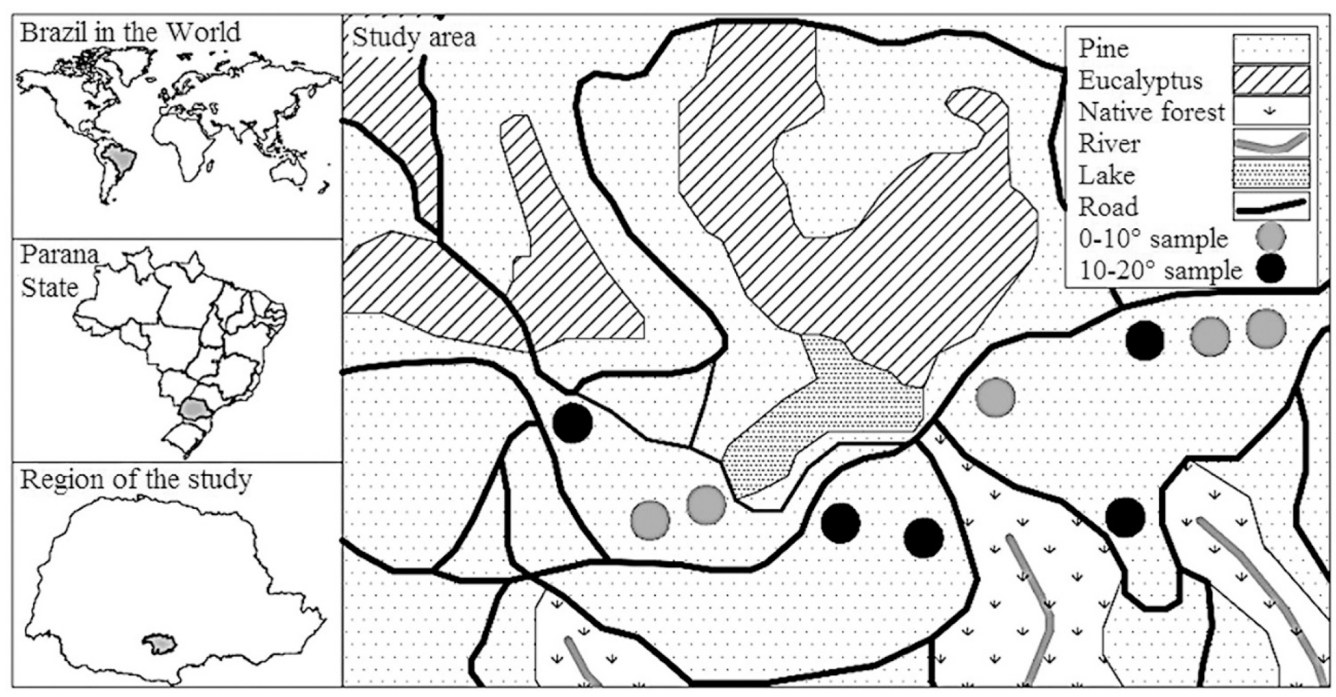

Figure 1. Study area.

Figura 1. Área de estudo. 
Data were collected in 12-year-old Pinus taeda L. stands submitted to the first thinning, with $2.0 \mathrm{x}$ $2.5 \mathrm{~m}$ planting spacing, $0.38 \mathrm{~m}^{3}$ of mean tree individual volume, and with the terrain slope classes varying from 0 to $10^{\circ}$ and 10 to $20^{\circ}$.

The mechanized wood harvesting system was a CTL composed of a harvester and a forwarder. Trees were felled, delimbed, and bucked (processed) directly in the stump area by the harvester and extracted to the roadside (off-road transport) by the forwarder.

The 6x6 wheeled harvester under study was equipped with wheel tracks, had a $228 \mathrm{hp}$ engine, a single-grip harvester head with $650 \mathrm{~mm}$ of cutting capacity, and a boom with a reach of $10 \mathrm{~m}$. The $8 \times 8$ wheeled forwarder under study was equipped with wheel tracks, had a $183 \mathrm{hp}$ engine, $15 \mathrm{t}$ of load capacity, and a boom with a reach of $10 \mathrm{~m}$. The machines' main dimensions are described in Figure 2.
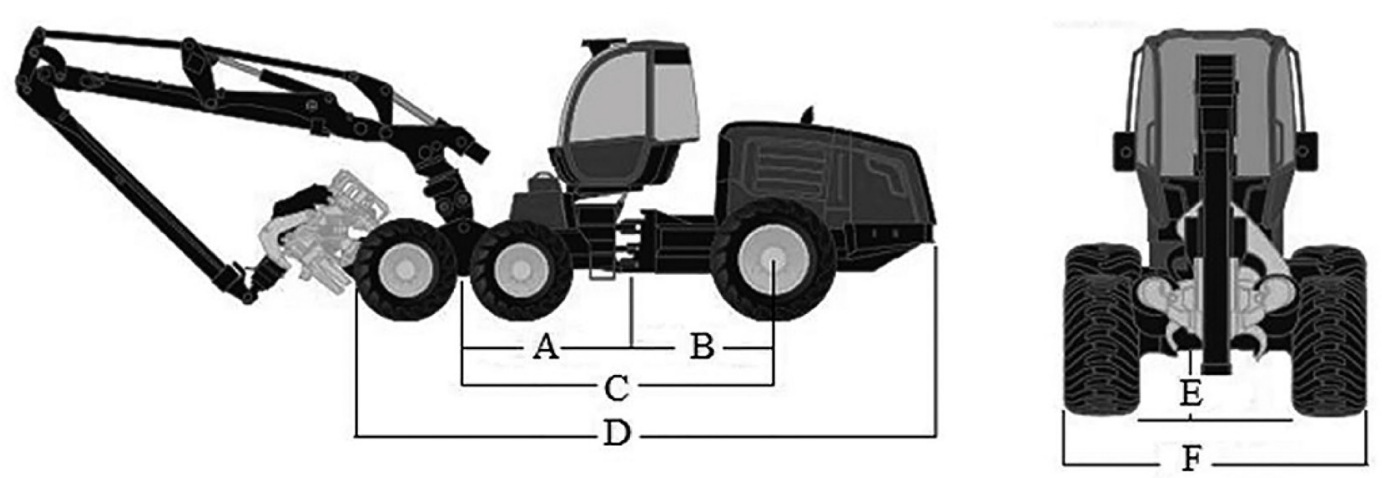

Harvester
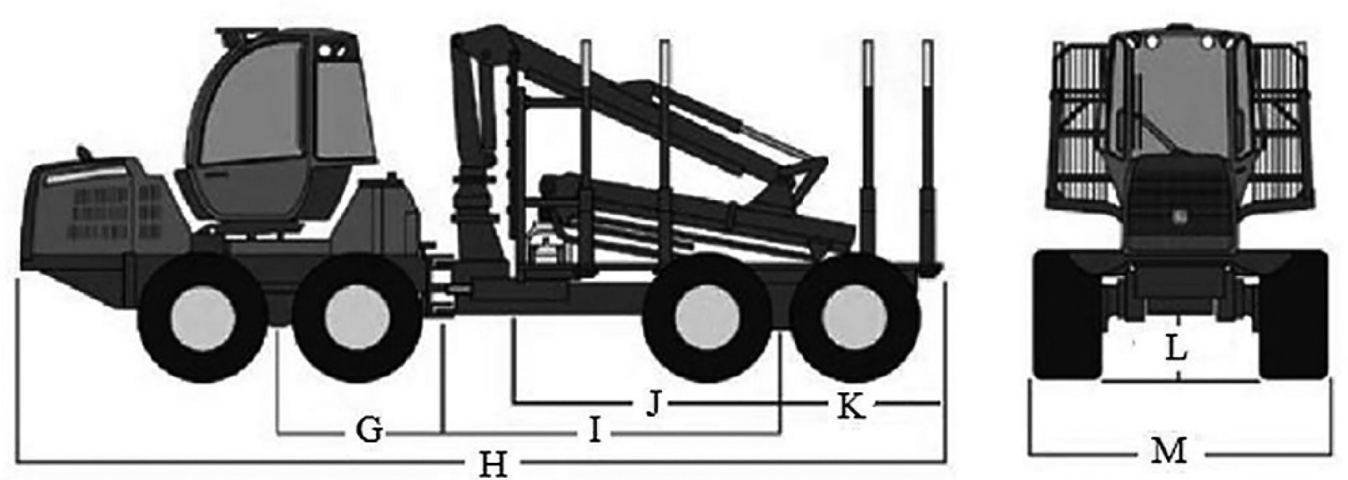

Forwarder

A) front axle - middle joint $=2,15 \mathrm{~m}$; B) middle joint - rear axle $=1,9 \mathrm{~m}$; C) length between axles $=4,05 \mathrm{~m}$; D) length = 7,55 m; E) ground clearance - middle joint $=0,6 \mathrm{~m} ; \mathrm{F}$ ) width $=2,17 \mathrm{~m}$; G) front bogie center - middle joint $=\mathrm{I}, 70 \mathrm{~m} ; \mathrm{H}$ ) length $=10,70 \mathrm{~m} ; \mathrm{I}$ ) middle joint - rear bogie center = $4 \mathrm{~m}$; J) headboard - bogie center = 2,6 m; K) bogie center - rear = I,90 m; L) ground clearance - middle joint $=0,66 \mathrm{~m}$; e $\mathrm{M}$ ) width $=2,95 \mathrm{~m}$.

Figure 2. Main measurements of the harvester and forwarder used in the thinning operation.

Figura 2. Principais medidas do harvester e do forwarder utilizados na operação de desbaste.

Systematic thinning was performed with a total cutting of the $5^{\text {th }}$ planting line that removed $20 \%$ of the trees to allow machine traffic inside the stand, while selective thinning was done to remove $20 \%$ of the previously selected trees (the dominated ones and those with lower volume) in both lines adjacent to the traffic trail. Both systematic and selective thinnings resulted in the removal of $40 \%$ of the trees from the stand (Figure 3 ).

\section{Data collection}

First, five sample units of $10 \times 52 \mathrm{~m}\left(520 \mathrm{~m}^{2}\right)$ were randomly installed in each class of land slope ( 0 to $10^{\circ}$ and 10 to $20^{\circ}$ ), with the center of the sample unit placed in the systematic thinning line.

Damage to residual trees was assessed from a 100\% survey conducted in each sample unit. The identified criteria were as follows: land slope, the damage-causing machine, the number of trees damaged by the machines, damage location (bottom trunk, trunk, or crown), trunk side of the damage (facing the operation trail, facing the stand, opposite to the trail, or facing the road), and damage area (dimension of the wound) using forms and checklists adapted from Cabral (2015). 

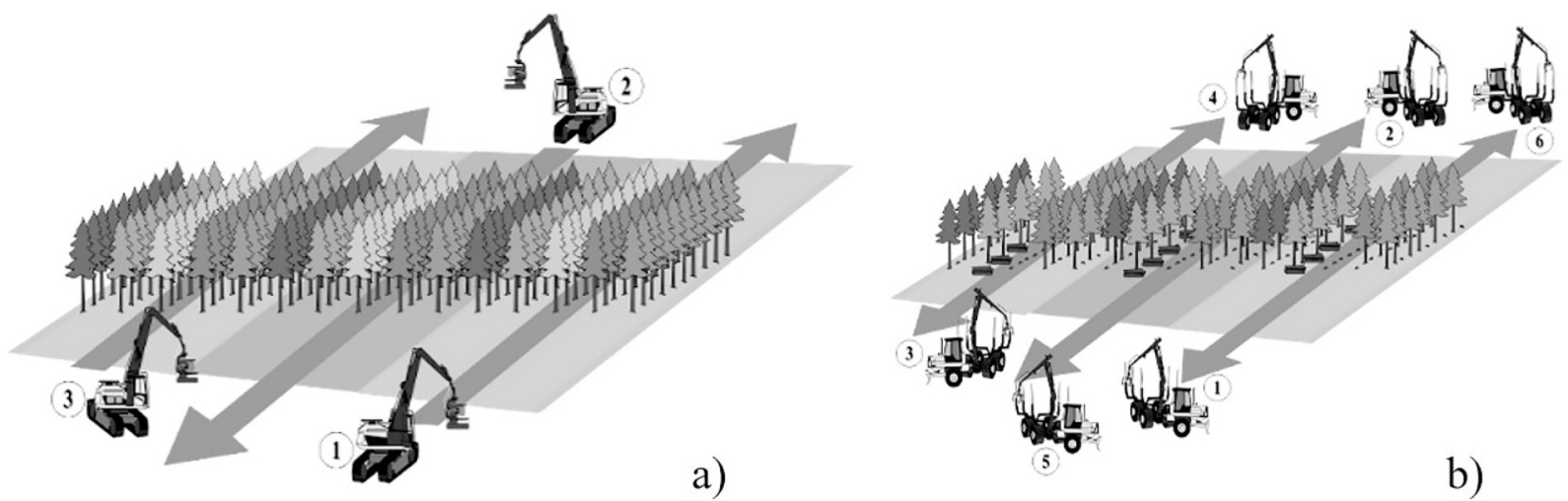

Figure 3. Thinning scheme performed in this study: a) harvester cutting; and b) forwarder extraction.

Figura 3. Esquematização do desbaste realizado neste estudo: a) corte com harvester; e b) extração com forwarder.

Data collection was performed after performing cutting and extraction operations with a harvester and a forwarder, respectively. Slope was measured by a clinometer, the damage-causing machine was identified by marking wounds with different color paints for each machine, the number of damaged trees and damage location was determined by counting, and damage area was measured by a checkered mesh with $1 \mathrm{~cm}^{2}$ squares.

\section{Statistical analysis}

A completely randomized design (CRD) in subdivided plots was used to analyze the number of damaged trees, and a CRD in sub-subdivided plots to analyze damage location and damage side. The results were submitted to an analysis of variance (ANOVA), and the means were compared by the t-test at a 5\% probability level. Damaged area was analyzed by its minimum, mean, and maximum values in order to emphasize the magnitude of damage occurrence.

\section{RESULTS}

Descriptive statistics related to observed damage values are presented in Table 1 . The total value is the sum of damages caused by both machines in the respective slope class.

Table 1. Mean damage caused by harvester and forwarder in different terrain slope classes.

Tabela 1. Danos médios causados pelo harvester e pelo forwarder em diferentes declividades do terreno.

\begin{tabular}{lccc|ccc}
\hline Slope & \multicolumn{3}{c|}{$\mathbf{0}$ to $\mathbf{1 0}^{\circ}$} & \multicolumn{3}{c}{$\mathbf{1 0}^{\text {to } \mathbf{2 0}^{\circ}}$} \\
\hline Machine & Harvester & Forwarder & Total & Harvester & Forwarder & Total \\
\hline Mean & 19.2 & 16.9 & 36.1 & 16.3 & 12.8 & 29.1 \\
Standard deviation & 6.8 & 5.1 & 10.7 & 1.9 & 3.8 & 2.9 \\
Minimum & 13.6 & 9.3 & 23.3 & 14.3 & 7.8 & 26.6 \\
Maximum & 26.9 & 23.1 & 50.0 & 18.9 & 16.8 & 33.5 \\
Amplitude & 13.3 & 13.8 & 26.7 & 4.6 & 9.1 & 6.9 \\
C. of variation & 35.3 & 30.1 & 29.7 & 11.5 & 30.0 & 10.0 \\
\hline
\end{tabular}

The highest percentage of tree damage was observed in the 0 to $10^{\circ}$ slope class, with a mean of $19.3 \%$ and $16.9 \%$, caused by both the harvester and forwarder, respectively. This highlights that the maximum damage values observed in the 0 to $10^{\circ}$ slope $(50.0 \%)$ were caused by both machines. On smaller slopes, machines tend to increase their productivity, which can reduce the operator's attention and the care which he takes to preserve the quality of residual trees.

Damage location (on the tree) and trunk side of damage are shown in Table 2.

It was observed that the trunk was the part of the tree that presented the greatest damage $(11.6 \%)$ and also the place that presented the maximum percentage value $(28.9 \%)$. As for the trunk side, the highest damage values were observed on the sides facing the stand and the road, with mean percentage values of $7.3 \%$ and $5.4 \%$, respectively. This was mainly due to the contact of the harvester boom and the felled trees against residual trees during the systematic thinning.

The results of the analysis of variance for damage percentage, damage location, and damage side are shown in Table 3. 
Table 2. Location on the tree and trunk side with damage occurrence caused by harvesting machines.

Tabela 2. Localização na árvore e face do tronco com ocorrência de danos causados pelas máquinas de colheita.

\begin{tabular}{lccc|cccc}
\hline Variable & \multicolumn{3}{c}{ Tree location (\%) } & \multicolumn{4}{c}{ Trunk side (\%) } \\
\hline Treatment & Bottom trunk & Trunk & Crown & Trail & Stand & Op. trail & Road \\
\hline Mean & 8.3 & 11.5 & 1.1 & 4.8 & 7.3 & 3.3 & 5.4 \\
Standard deviation & 5.9 & 6.3 & 1.9 & 5.9 & 6.5 & 2.0 & 3.8 \\
Minimum & 1.9 & 1.9 & 0.0 & 1.9 & 0.0 & 0.0 & 0.0 \\
Maximum & 26.9 & 28.9 & 7.8 & 26.9 & 25.0 & 7.8 & 13.7 \\
Amplitude & 25.0 & 27.0 & 7.8 & 25.0 & 25.0 & 7.8 & 13.7 \\
Coefficient of variation & 70.7 & 54.6 & 181.3 & 123.9 & 89.8 & 59.3 & 70.3 \\
\hline
\end{tabular}

Table 3. Results of the analysis of variance for the three experimental designs.

Tabela 3. Resultados da análise de variância para os três delineamentos experimentais.

\begin{tabular}{llc}
\hline Variable & Source & p-value \\
\hline \multirow{3}{*}{ Damage percentage } & Slope & 0.2898 \\
& Machine & 0.3020 \\
& Interaction: slope X machine & 0.8397 \\
\hline & Slope & 0.2842 \\
& Machine & 0.2906 \\
Damage location & Interaction: slope X machine & 0.8761 \\
& Tree location & $<0.0001$ \\
& Interaction: slope X tree location & 0.5585 \\
& Interaction: machine X tree location & 0.2454 \\
& Interaction: slope X machine X tree location & 0.1529 \\
\hline Slope & 0.2848 \\
& Machine & 0.2303 \\
& Interaction: slope X machine & 0.8793 \\
& Damage side & 0.0225 \\
& Interaction: slope X damage side & 0.0739 \\
& Interaction: machine X damage side & 0.1783 \\
\hline
\end{tabular}

There was no interaction between any treatments in the three experimental designs. It is understood that the treatment effects are independent; this means the occurrence of damage to the residual trees does not depend on the machine type (a harvester or a forwarder) nor the slope ( 0 to $10^{\circ}$ or 10 to $\left.20^{\circ}\right)$. However, the factors of damage location and damage side showed significant differences (p-values $<0.01$ and $<0.05$, respectively) and could be analyzed by the means comparison t-test (Table 4).

Table 4. Results of the t-test for comparing means of damage (\%) in the two variables indicated by the analysis of variance.

Tabela 4. Resultados do teste t para comparação das médias de danos (\%) nas duas variáveis indicadas pela análise de variância.

\begin{tabular}{llc}
\hline Variable & Treatment & Mean damage values (\%) \\
\hline \multirow{3}{*}{ Damage location } & Bottom trunk & $8.31 \mathrm{~b}$ \\
& Trunk & $11.55 \mathrm{a}$ \\
& Crown & $1.08 \mathrm{c}$ \\
\hline \multirow{3}{*}{ Trunk side } & Facing the operation trail & $4.75 \mathrm{~b}$ \\
& Facing the stand & $7.28 \mathrm{a}$ \\
& Opposite to the trail & $3.30 \mathrm{~b}$ \\
\hline
\end{tabular}

Means followed by the same letter do not differ statistically by $t$-test at $5 \%$ probability level.

For the variable damage location, the t-test revealed that the mean of trunk damage was superior and statistically different in relation to the means of other tested treatments. This is possibly due to the region of greatest contact between the residual trees and certain parts of the harvesting machines (boom, harvesting head, wheels), and with the trees felled in the selective thinning. For the variable damage side, the highest occurrence was observed in the sides facing the stand and the road, with no significant difference between them. Thus, it can be inferred that the majority of trunk damages 
Lopes et al. - Damage to residual trees following commercial thinning

by harvester and forwarder in a Pinus taeda stand in Southern Brazil

occurred due to operations of selective thinning during the activity of pulling the felled trees in selective thinning for later processing at the operation trail, as shown in Figure 4.
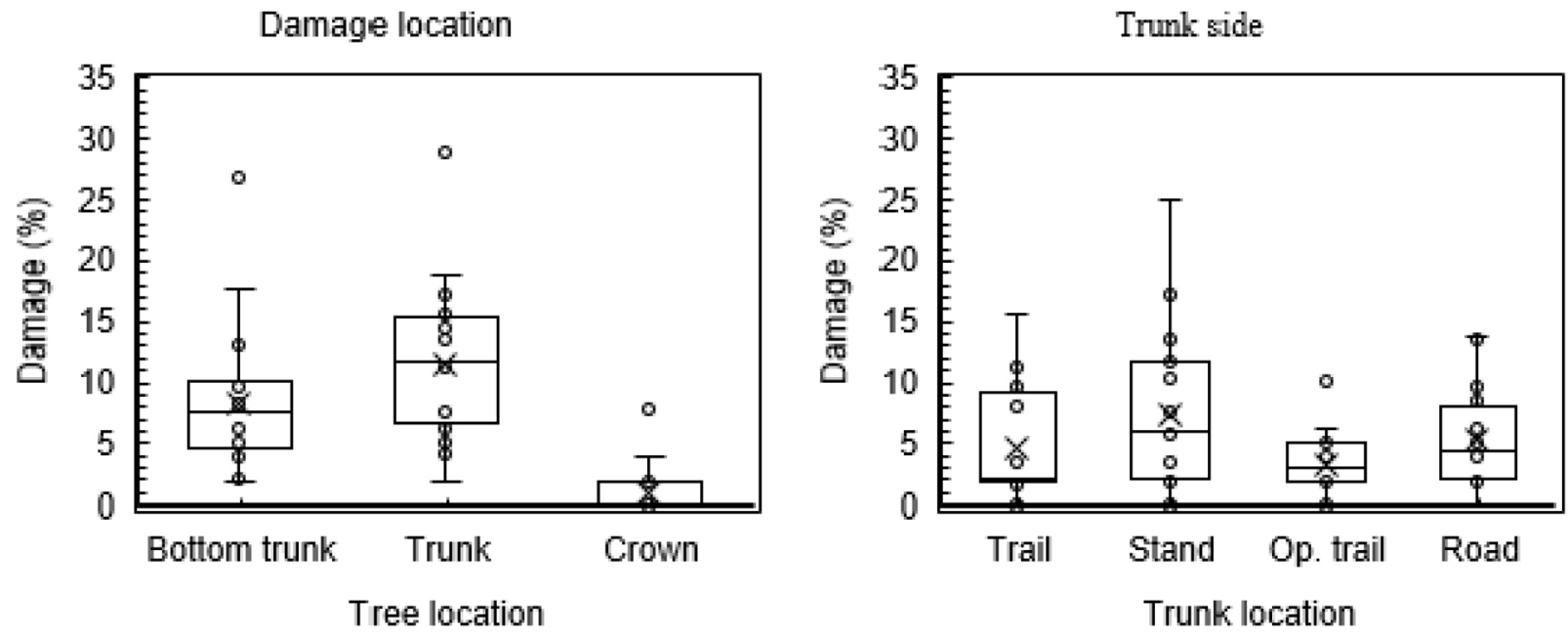

Figure 4. Damage distribution by location and occurrence side caused by the harvester and the forwarder.

Figura 4. Distribuição dos danos por localização e face de ocorrência, causados pelo harvester e pelo forwarder.

Mean, minimum, and maximum values for damage area (wound dimensions) are shown in Figure 5. Damage presented, on average, less than $100 \mathrm{~cm}^{2}$ area in all treatments; but there were values close to $600 \mathrm{~cm}^{2}$.
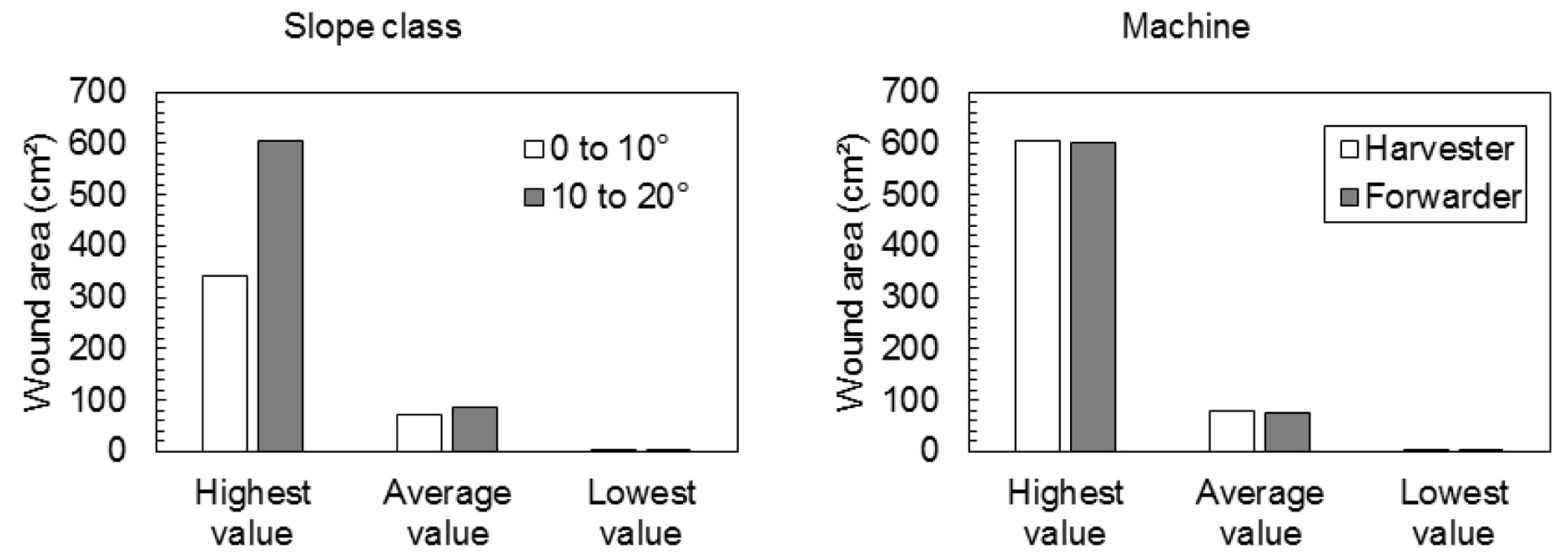

Trunk side

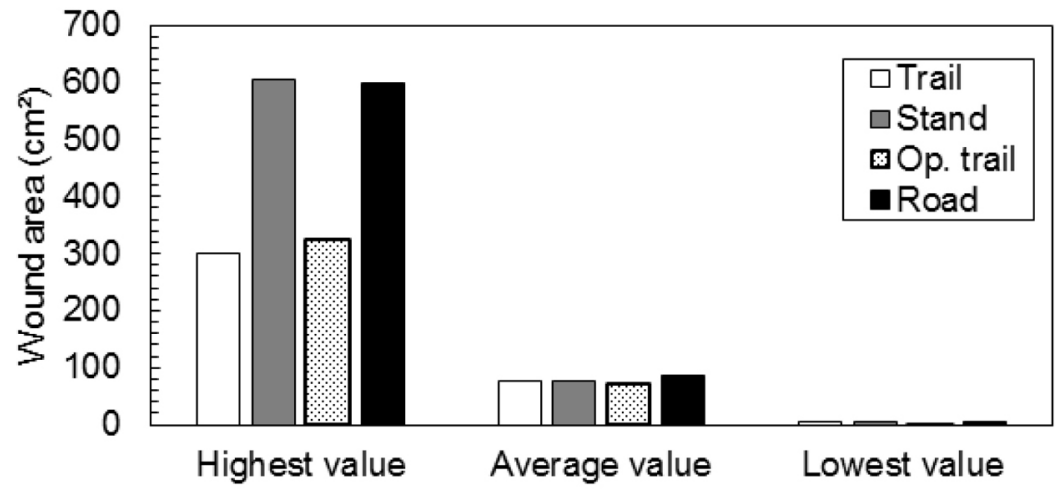

Figure 5. Damage areas caused by harvesting machines in different slope classes and trunk sides.

Figura 5. Áreas dos danos causados pelas máquinas de colheita nas diferentes classes de declividade e faces do tronco.

The largest wound areas were observed on the slope from 10 to $20^{\circ}$, and were caused by both the harvester and forwarder; thus, proving that it is more difficult to execute the operation on gre- 
ater slopes of terrain. It was also observed that the greatest damage percentage occurred on sides facing the stand and the road, both in quantity and in relation to the wound area, with a significant difference in relation to other trunk sides. This suggests that the largest damaged area was caused by the selective thinning operation due to the contact of certain harvesting machine parts (boom, harvesting head, wheels) and between the felled trees (selective thinning) and the residual trees.

\section{DISCUSSION}

The percentage of damage to residual trees caused by both the harvester and forwarder in both slopes was considered high, being higher than that obtained by Cabral (2015), Lineros (2003) and Landford e Stokes (1995), with $13.0 \%, 12.3 \%$, and 10.0\%, respectively. The highest damage percentage occurred in selective thinning operations due to the greater difficulty of the harvester in tree searching, felling, and processing inside the stand. This caused mechanical damage in the residual trees, and therefore could spoil forest growth and decrease commercial value, not to mention the occurrence of pathogens and pests, and consequently reduced wood quality.

It is important to emphasize that the maximum acceptable damage value reported in the literature is $6 \%$, where several authors obtained damage values close to and lower than those in this study (FRÖDING, 1992; McNEEL; BALAARD, 1992; SAUTER, 1996; SIRÉN, 2001; VIDRINE et al., 1999). As for the terrain slope, the highest damage percentage was verified in the 0 to $10^{\circ}$ class and mainly caused by the harvester, with a greater value than the maximum acceptable values verified in other studies.

In addition to the high damage values originated by the harvester in the 0 to $10^{\circ}$ slope class, the treatment presented a high coefficient of variation, indicating that the machine did not perform the activity with a predetermined pattern and caused damage of different intensities inside the stand.

It can be highlighted that most of the damage caused by wood harvesting machines occurred on the trunk: which is the part with the highest commercial value. Vasiliauskas (2001) reported that, in addition to the economic question, trunk sections with larger diameters are the most sensitive, with the possibility of the wound not closing, therefore open to being attacked by fungi and insects. This trunk damage causes significant losses in forest growth and wood quality; Wästerlund (1992) stated that damage can result in up to $20 \%$ loss of growth and forest volume.

The operation trail's limited space further exacerbates damage occurrence. Unlike clear-cutting harvest operations, thinning operation machines move in trails opened by systematic thinning and have a limited width to operate. In this study, the operation trail was 4.0 meters wide, while the harvester and forwarder had widths of 2.17 and $2.95 \mathrm{~m}$, respectively. Thus the machines touched the trunks of residual trees with their wheels many times during cutting operations or during other machine movements. This situation tends to occur more frequently in wheeled machines because they are larger than the tracked ones commonly used in thinning operations.

The lack of interaction between the land slopes, and between them and the machines (reported by statistical analysis) added to the high damage percentage. This can be considered as suggestive for readjusting the whole thinning operation, from the correct choice of machines to the improvement of working techniques, aiming at minimizing damage throughout the thinning operation.

As measures to reduce damage to residual trees, we can mention the use of tracked machines rather than wheeled ones, since according to Spinelli (2004) and Lageson (1997), the type of machine to be used is one of the greatest influencing factor during the operation. In addition, smaller-scale mechanized machines could be used, such as All-Terrain Vehicles (ATVs) studied by Savelli et al. (2010), aiming at minimizing the impacts on the site and reducing the high cost of harvesting operations.

\section{CONCLUSIONS}

There was a high percentage of residual trees damaged by both the harvester and forwarder while performing mechanized thinning. This situation could compromise future residual tree growth, wood quality, and the sustainability of forest production.

The land slope class and the type of machine used to harvest the wood did not affect the occurrence of damage. In other words, they caused the same damage intensity to residual trees in the stands submitted to thinning. 
Lopes et al. - Damage to residual trees following commercial thinning

by harvester and forwarder in a Pinus taeda stand in Southern Brazil

The highest damage intensity occurred in the lower parts of trees (trunk and bottom trunk), which are considered the most valuable commercial parts.

The most affected trunk sides were those facing the interior of the stand and the road, also presenting greater damage areas due to harvester operation in selective thinning.

Damage observed in the forest stand revealed the need to choose a smaller machine to provide better conditions for thinning in Pinus taeda L. stands and cause less damage to residual trees.

\section{REFERENCES}

BELBO, $\mathrm{H}$. Whole tree harvesting in early thinnings and landscape management. In: SUADICANI, K.; TALBOT, B. The Nordic-Baltic Conference on Forest Operations. Hørsholm: University of Copenhagen, Forest \& Landscape Denmark, 2008. 92 p. (Working Papers, 30)

CABRAL, O. M. J. V. Avaliação operacional da colheita de madeira em desbastes de Pinus taeda L. 2015. 110 p. Dissertação (Mestrado em Engenharia Florestal) - Setor de Ciências Agrárias, Universidade Estadual do Centro-Oeste, Irati, 2015. 110 p.

FRÖDING, A. Thinning damage, a study of 403 stands in Sweden in 1988. Sweden: Sveriges Lantbruks Universitet, Institutionen fr Skogsteknik, 1992. 45 p. (Report 193)

HAN, H. S.; KELLOGG, L. Damage characteristics in young Douglas-fir stands from commercial thinning with four timber harvesting systems. Western Journal of Applied Forestry, Laramie, v. 15, n. 1, p. 27-33, 2000.

HARSTELA, P. The future of timber harvesting in Finland. Journal of Forest Engineering, v. 10, n. 2, p. 33-36, 1999.

IBÁ - BRAZILIAN TREE INDUSTRY. IBÁ 2016. São Paulo: IBA, 2016. 100 p.

LAGESON, H. Effects of thinning type on the harvester productivity and on the residual stand. International Journal of Forest Engineering, v. 8, n. 2, p. 7-14, 1997.

LANDFORD, B. L.; STOKES, B. J. Comparison of two thinning systems, Part I: Stand and site impact. Forest and Products Journal, v. 45, n. 4, p. 74-96, 1995.

LINEROS, M.; ESPINOSA, M.; JIMENEZ, A. Daño a los árboles remanentes por sistema harvester-forwarder en raleo comercial de Pinus radiata D. Don. Bosque, Valdivia, v. 24, n. 1, p. 87-93, 2003.

LOPES, E. S.; DINIZ, C. C. C.; SERPE, E. L.; CABRAL, O. J. M. V. Efeito do sortimento da madeira na produtividade e custo do forwarder no desbaste comercial de Pinus taeda. Scientia Forestalis, Piracicaba, v. 44, n. 109, p. 57-66, 2016.

MALINOVSKI, R. A.; MALINOVSKI, R. A.; MALINOVSKI, J. R.; YAMAJI, F. M. Análise das variáveis de influência na produtividade das máquinas de colheita de madeira em função das características físicas do terreno, do povoamento e do planejamento operacional florestal. Revista Floresta, Floresta, v. 36, n. 2, p. 169-182, 2006.

MALINOVSKI, R. A.; MALINOVSKI, R. A.; MALINOVSKI, J. R. Os Impactos da colheita de madeira sobre o povoamento remanescente. In: SIMPÓSIO INTERNACIONAL SOBRE ECOSSISTEMAS FLORESTAIS. 5., 1999, Curitiba. Anais... Curitiba: FUPEF, 1999.

MCNEEL, J. F.; BALLARD, T. M. Analysis of site stand impacts from thinning with a harvester-forwarder system. Journal of Forest Engineering, v. 4, n. 1, p. 23-29, 1992.

MULLER, P.; ANGELI, A. Implantação e manejo de florestas comerciais: Documentos florestais IPEF, Piracicaba, n. 18, 2006. 14 p. 
OLIVEIRA, D.; LOPES, E. S.; FIEDLER, N. Avaliação técnica e econômica do forwarder na extração de toras de Pinus. Scientia Forestalis, Piracicaba, v. 37, n. 84, p. 525-533, 2009.

PETTY, A.; KÄRHÄ, K. Kemera supports and the profitability of small-sized wood harvesting from early thinnings in Finland. THE NORDIC-BALTIC CONFERENCE ON FOREST OPERATIONS. 2008, Hørsholm. Proceedings... Hørsholm: Forest \& Landscape Denmark, University of Copenhagen, 2008. p. 46-47.

RUMMER, B. Forest operations technology. In: WEAR, D.; GREIS, J. Southern forest resource assessment. Asheville: USDA, Forest Service, Southern Research Station, 2002. Cap. 15, p. 341- 353.

SAUTER, U. H. Modern highly mechanized wood harvesting systems: comparison for long and short wood cutting system using harvesting for thinning conifer stand in regard of stand damages, performance and volume output. In: SEMINÁRIO DE ATUALIZAÇÃO SOBRE SISTEMAS DE COLHEITA DE MADEIRA. 9., 1996, Curitiba. Anais... Curitiba: FUPEF, 1996.

SAVELLI, S.; CAVALLI, R.; BALDINI, S.; PICCHIO, R. Small scale mechanization of thinning in artificial coniferous plantation. Croatian Journal of Forest Engineering, v. 31, p. 11-21, 2010.

SCHNEIDER, P. R.; SCHNEIDER, P. Introdução ao manejo florestal. Santa Maria: FACOS-UFSM, 2008. 566 p.

SIRÉN, M. Tree damage in single-Grip harvester thinning operations. International Journal of Forest Engineering, v.12, n.1, p.29-38, 2001.

SPINELLI, R. Harvesting of thinnings. Florence: National Council for Research, Timber and Tree Institute, 2004. $6 \mathrm{p}$.

SPINELLI, R.; NATI, C. A. Low-Investment fully mechanized operation for pure selection thinning of pine plantations. Croatian Journal of Forest Engineering, v. 30, n. 2, p. 89-97, 2009.

VASILIAUSKAS, R. Damage to trees due to forestry operations and its pathological significance in temperate forests. Journal of Forestry, Bethesda, v. 74, n. 4, p. 319-336, 2001.

VIDRINE, C.; DEHOOP, C.; LANFORD, B. Assessment of site and stand disturbance from cut-to-length harvesting. In: HAYWOOD, J. D. (ed.), BIENNIAL SOUTHERN SILVICULTURAL RESEARCH CONFERENCE. 10., 1999, Shreveport. Proceedings... Shreveport: USDA Forest Service, Southern Research Station, 1999. p. 16-18.

WÄSTERLUND, Y. Extent and causes of site damage due to forestry traffic. Scandinavian Journal of Forestry Research, v. 7, n.1-4, p. 135-142, 1992.

Received on 02/09/2017

Accepted on 10/24/2017

Sci. For., Piracicaba, v. 46, n. 118, p. 167-175, jun. 2018 DOI: dx.doi.org/10.18671/scifor.v46n118.03 
